\title{
The Metabolism of Cellulose, Glucose and Starch by the Rumen Ciliate Protozoon Eudiplodinium maggii
}

\author{
By GEOFFREY S. COLEMAN \\ Biochemistry Department, Agricultural Research Council, \\ Institute of Animal Physiology, Babraham, Cambridge CB2 4 AT
}

(Received 8 February 1978)

\begin{abstract}
Washed suspensions of the rumen ciliate protozoon Eudiplodinium maggii incubated anaerobically in the presence of ampicillin utilized cellulose and to a lesser extent starch, but not soluble sugars. The protozoon incorporated ${ }^{14} \mathrm{C}$ from ${ }^{14} \mathrm{C}$-labelled cellulose, glucose and starch; it synthesized protein from these compounds but only at a rate that would allow for the protozoa to divide every 8300,1200 and $580 \mathrm{~h}$, respectively, if this were the sole source of protein. These substrates were also metabolized with the production of acetic, propionic and butyric acids. Evidence is presented that $70 \%$ of the cellulase inside the protozoa is soluble and not of bacterial origin. It had an activity of 11 to $28 \mathrm{pg}$ cellulose digested $\mathrm{h}^{-1}$ protozoon ${ }^{-1}$ [0.55 to $3.3 \mu$ g cellulose digested $\mathrm{h}^{-1}$ (mg protein) ${ }^{-1}$ ].
\end{abstract}

\section{INTRODUCTION}

Hungate (1942) first grew Eudiplodinium maggii in vitro in the presence of bacteria and showed, by microscopical examination of starved protozoa, that they converted cellulose into 'paraglycogen' and that protozoal extracts produced sugar from cellulose. Recently, $E$. maggii has been shown to grow better on ground, dried grass than on wholemeal flour and to contain enzymes that liberate soluble ${ }^{14} \mathrm{C}$-labelled compounds from an insoluble preparation of $\left[{ }^{14} \mathrm{C}\right]$ cellulose (Coleman et al., 1976). The present paper describes the metabolism of $\left[{ }^{14} \mathrm{C}\right]$ cellulose, $\left[{ }^{14} \mathrm{C}\right]$ starch grains and $\left[{ }^{14} \mathrm{C}\right]$ glucose by washed suspensions and extracts of E. maggii grown in vitro or as the only ciliate protozoon in the rumen of a sheep.

\section{METHODS}

Organism. Eudiplodinium maggii was grown in vitro on ground, dried grass as the sole source of carbon, apart from contaminating bacteria, as described by Coleman et al. (1976). The work was carried out with four separate isolates ( $\mathrm{CO} 2,4 \mathrm{~L}, \mathrm{C}$ and $\mathrm{w}$ ) all of which behaved similarly, although they varied in size from $102 \times 62 \mu \mathrm{m}$ (isolate c) to $150 \times 75 \mu \mathrm{m}$ (isolate $\mathrm{co} 2$ ). Washed suspensions were prepared as described by Coleman (1969) except that mineral salt solution $\mathrm{D}$ [containing $\left(\mathrm{g} \mathrm{l}^{-1}\right): \mathrm{K}_{2} \mathrm{HPO}_{4}, 6 \cdot 3 ; \mathrm{KH}_{2} \mathrm{PO}_{4}, 5 \cdot 0 ; \mathrm{NaCl}$, $0.65 ; \mathrm{CaCl}_{2}$ (dried), $0.045 ; \mathrm{MgSO}_{4} .7 \mathrm{H}_{2} \mathrm{O}, 0.09$ ] was used throughout. All suspensions inevitably contained some grass since this protozoon sedimented at almost the same rate as the plant material on which it was grown.

As the protozoal population density in culture was 100 to $200 \mathrm{ml}^{-1}$, it was difficult to obtain sufficiently large numbers of protozoa for some metabolic experiments. For these, the protozoa were harvested from the rumen contents of a Clun Forest sheep (fed on $800 \mathrm{~g}$ hay and $100 \mathrm{~g}$ oats daily) that had been treated initially with the dioctyl ester of sodium sulphosuccinate (Abou Akkada et al., 1968) to kill all the ciliate protozoa and then refaunated with $E$. maggii from a laboratory culture. To harvest the protozoa, rumen contents were strained through one layer of muslin and then allowed to stand for $30 \mathrm{~min}$ in a separating funnel at $39{ }^{\circ} \mathrm{C}$. The protozoa which sedimented to the bottom of the funnel were run off and washed at least six times by gentle centrifugation (on a swing-out-head centrifuge for $20 \mathrm{~s}$ from rest, maximum speed equivalent to $200 \mathrm{~g}$ ) in salt solution $\mathrm{D}$ at room temperature. As much as possible of the green layer that 
sedimented above the protozoa was removed. Rumen- or in vitro-grown protozoa were finally resuspended in salt solution $\mathrm{D}$ containing $0.1 \%(\mathrm{w} / \mathrm{v})$ L-cysteine hydrochloride (neutralized with $\mathrm{NaOH}$ ) and bubbled for 2 min with $\mathrm{N}_{2} / \mathrm{CO}_{2}(95: 5, \mathrm{v} / \mathrm{v})$ before use.

Incubation conditions. The medium contained: 0 to $0.2 \mathrm{ml}{ }^{14} \mathrm{C}$-labelled cellulcse, starch grains or glucose; 0 to $0.1 \mathrm{ml} 0.3 \%(\mathrm{w} / \mathrm{v})$ chloramphenicol or $1.0 \%(\mathrm{w} / \mathrm{v})$ ampicillin; $1.0 \mathrm{ml}$ suspension $\left(500\right.$ to $\left.100000 \mathrm{ml}^{-1}\right)$ of intact or, where indicated, sonicated protozoa; and 0 to $0.45 \mathrm{ml}$ salt solution D containing $0.1 \%$ cysteine hydrochloride, to give a final volume of $1.5 \mathrm{ml}$. Thick-walled centrifuge tubes $(100 \times 13 \mathrm{~mm})$ were used; after inoculation $\mathrm{N}_{2} / \mathrm{CO}_{2}(95: 5, \mathrm{v} / \mathrm{v})$ was bubbled through the medium for $15 \mathrm{~s}$ at room temperature and the tube was then sealed with a rubber bung and incubated at $39^{\circ} \mathrm{C}$. For experiments on the survival of protozoa, unlabelled substrates were used and extra salt solution $\mathrm{D}$ containing $0.1 \%$ cysteine hydrochloride was added to make the final volume $3.0 \mathrm{ml}$.

After incubation, intact protozoa were gently centrifuged (see above) and washed $(\times 3)$ in salt solution D at room temperature. The washed protozoa were then either plated out for the determination of radioactivity (Coleman, 1969) or suspended in $2 \mathrm{ml} \mathrm{H}_{2} \mathrm{O}$ and disrupted (see below). Any bacteria present and most of the cellulose or starch grains that had not been engulfed were sedimented from the first supernatant fluid obtained after removal of the protozoa and washed once $\left(2000 \mathrm{~g}, 20 \mathrm{~min}, 4^{\circ} \mathrm{C}\right.$, on an angle-head centrifuge). Samples from the supernatant fluid after removal of the bacteria were placed on planchets with $0.1 \mathrm{ml} 1 \mathrm{M}$ $\mathrm{HCl}$ or $0.1 \mathrm{ml} 0.1 \mathrm{M}-\mathrm{NaOH}$ for estimation of ${ }^{14} \mathrm{C}$ which was free in the medium. The radioactivity determined with $\mathrm{HCl}$ measured the non-volatile ${ }^{14} \mathrm{C}$ and the difference between the determinations in the presence of $\mathrm{HCl}$ and $\mathrm{NaOH}$ measured the ${ }^{14} \mathrm{C}$ in volatile fatty acids.

Disruption of protozoa by sonication. The tube containing the protozoal suspension was immersed in an ultrasonic cleaning bath of average output $40 \mathrm{~W}$ and frequency $80 \mathrm{kHz}$ at room temperature until no protozoa could be detected microscopically, as described by Coleman \& Laurie (1977). The crude homogenate was centrifuged $\left(5500 \mathrm{~g}, 20 \mathrm{~min}, 4^{\circ} \mathrm{C}\right)$, the supernatant fluid was termed the broken-cell supernatant fluid and the pellet, after washing once by centrifuging in salt solution $\mathrm{D}$, was the broken-cell pellet. When the protozoa were disrupted before incubation, the homogenate was centrifuged and the pellet was washed $(\times 3)$ in salt solution $\mathrm{D}\left(5500 \mathrm{~g}, 20 \mathrm{~min}, 4^{\circ} \mathrm{C}\right)$ before plating out for the determination of radioactivity. This pellet was similar to the broken-cell pellet referred to above and contained any bacteria, polysaccharide granules and cellulose that had been present in the protozoa.

Preparation of $\left[{ }^{14} \mathrm{C}\right]$ cellulose and $\left[{ }^{14} \mathrm{C}\right]$ starch grains. These were prepared as described by Coleman $e$ al . (1976) and Coleman (1969), respectively, and had specific activities of 2820 and 505 c.p.m. $\mu \mathrm{g}^{-1}$, respectively. The dry $\alpha$-cellulose was stored at $4{ }^{\circ} \mathrm{C}$ and phosphoric acid-regenerated cellulose was prepared from this as required.

Cellulase. This was assayed as described by Coleman et al. (1976) except that after incubation $0 \cdot 1 \mathrm{ml}$ of $1 \%$ $(\mathrm{w} / \mathrm{v})$ haemoglobin was added to each tube before immersion in boiling water for $5 \mathrm{~min}$. Each assay tube contained 2.5 to $9.0 \mu \mathrm{g}\left[{ }^{14} \mathrm{C}\right]$ cellulose $(7000$ to 25000 c.p.m.) depending on the batch of phosphoric acidregenerated cellulose used. As all batches had the same specific activity and as the amount of ${ }^{14} \mathrm{C}$ released during the assay was proportional to the amount of $\left[{ }^{14} \mathrm{C}\right] c e l l u l o s e$ added, it was possible to compare activities measured with different cellulose preparations. Under standard conditions cellulase activities were calculated

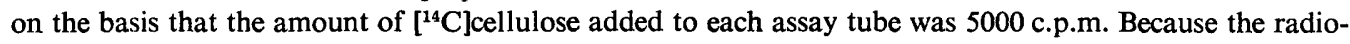
activity released from $\left[{ }^{14} \mathrm{C}\right]$ cellulose was not proportional to the amount of enzyme solution added, results of experiments on the comparison of the cellulase activities in different preparations from the same protozoal suspension are expressed relative to that in the broken-cell supernatant fluid by reference to a calibration curve such as that shown in Fig. 3. It is assumed that there is the same relationship between cellulose digested and enzyme concentration in all preparations.

Other procedures. Protozoa were fractionated as described by Coleman (1969). The number of protozoa was estimated as described by Coleman et al. (1976). Protein was determined by the method of Lowry $e$ t al. (1951). Cellulose was hydrolysed as described by Jermyn (1955) and the glucose content was determined by the method of Huggett \& Nixon (1957). Volatile fatty acids were separated directly from acidified incubation media (after removal of particulate matter) by gas-liquid chromatography on a $1.8 \mathrm{~m} \times 6 \mathrm{~mm}$ glass column packed with $20 \% \mathrm{n}$ eopentyl g lycol adipate on $60 / 85$ Universon $\mathrm{B}$ at $120^{\circ} \mathrm{C}$. Eluted comrounds were identified by comparison of the retention times with those of known acids. The amounts of the fatty acids were calculated from retention time $\times$ peak height by reference to those of known amounts of the same compounds.

\section{RESULTS}

\section{Survival of washed suspensions}

The number of $E$. maggii in a washed suspension incubated anaerobically in the presence of ampicillin ( $1 \mathrm{mg} \mathrm{ml}^{-1}$ ) declined to nil after $2 \mathrm{~d}$ in the absence of substrate but remained 


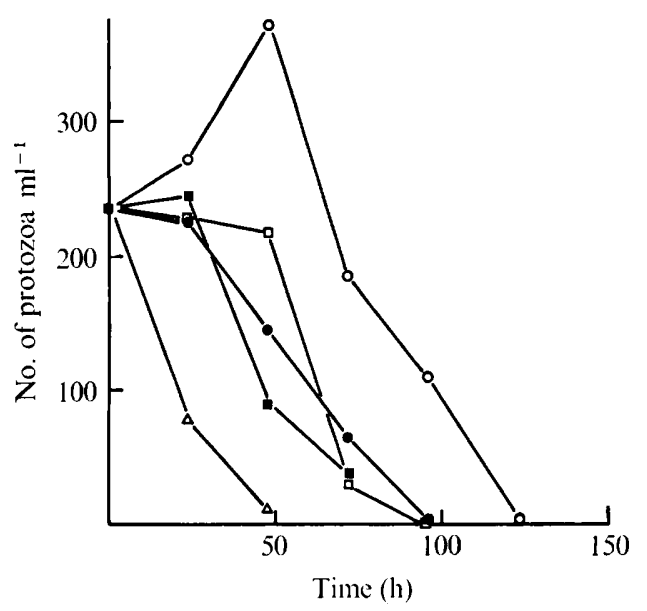

Fig. 1. Survival of washed suspensions of Eudiplodinium maggii $\left(235 \mathrm{ml}^{-1}\right)$ incubated anaerobically with ampicillin $\left(1 \mathrm{mg} \mathrm{ml}^{-1}\right)$ alone $(\triangle)$, or with ampicillin and the following additions $\left(0.7 \mathrm{mg} \mathrm{ml}^{-1}\right)$ : , cellulose; $\bigcirc$, cellulose and $10 \%(\mathrm{v} / \mathrm{v})$ prepared fresh rumen fluid; $\square$, rice starch; $\square$, rice starch and $10 \%(\mathrm{v} / \mathrm{v})$ prepared fresh rumen fluid.

constant for $2 \mathrm{~d}$ in the presence of cellulose (Sigma, MN;0.7 mg ml-1) (Fig. 1). The further addition of $10 \%(\mathrm{v} / \mathrm{v})$ prepared fresh rumen fluid (from which the protozoa had been removed; Coleman, 1958) increased the protozoal population density by $60 \%(100 \%$ in one experiment) after $2 \mathrm{~d}$. At most times there were fewer protozoa in the presence of rice starch than cellulose suggesting that with protozoa grown in vitro on dried grass as the sole source of food, cellulose was the preferred substrate. Glucose or cellobiose $(0.2 \%, \mathrm{w} / \mathrm{v}) \mathrm{did}$ not improve survival over that in the absence of substrate.

\section{Metabolism of intact protozoa}

Cellulose. It was difficult to obtain an accurate estimate of the amount of $\left[{ }^{14} \mathrm{C}\right]$ cellulose fermented because residual cellulose could not be completely separated from protozoa which also contained undigested cellulose and polysaccharide granules derived from cellulose. On incubation of $E$. maggii (10500 organisms of isolate w grown in vitro) with $\left[{ }^{14} \mathrm{C}\right]$ cellulose $(46.5 \mu \mathrm{g})$ for $48 \mathrm{~h}$ in the presence of ampicillin $\left(1 \mathrm{mg} \mathrm{ml}{ }^{-1}\right), 34 \%$ of the ${ }^{14} \mathrm{C}$ not present in particulate form appeared as volatile fatty acids and $2 \%$ as non-volatile material in the medium. The remainder, which was not retained on the planchet in the presence of $\mathrm{NaOH}$, was probably $\mathrm{CO}_{2}$. Of the ${ }^{14} \mathrm{C}$ found in the protozoal fraction, 1 to $5 \%$ (depending on the experiment) was in the broken-cell supernatant fluid and of this, $42 \%$ was in the residual protein (principally as alanine, aspartic acid and glutamic acid), $38 \%$ in the pool and $20 \%$ in the hot trichloroacetic acid (TCA)-soluble fraction. On further hydrolysis of this material $\left(1 \mathrm{M}-\mathrm{HCl}, 100{ }^{\circ} \mathrm{C}, 1 \mathrm{~h}\right)$, the products were glucose $(94 \%)$ and a pentose, probably ribose $(6 \%)$. As undigested cellulose was present in the broken-cell pellet, it was not possible to measure the incorporation of ${ }^{14} \mathrm{C}$ into fractions of this material. However, after hydrolysis by $\mathrm{HCl}$ of the material soluble in hot $\mathrm{TCA},\left[{ }^{14} \mathrm{C}\right]$ glucose was the only product, suggesting that the ${ }^{14} \mathrm{C}$ was present as a glucose polysaccharide such as starch. To determine if the ${ }^{14} \mathrm{C}$-labelled protein found in the broken-cell supernatant fluid was the product of bacterial action, the rate of synthesis was measured over $6 \mathrm{~h}$ in the presence and absence of chloramphenicol $\left(80 \mu \mathrm{g} \mathrm{m}^{-1}\right)$ (an inhibitor of bacterial protein synthesis), and was found to be 1.9 and $2.9 \mathrm{pg} \mathrm{h}^{-1}$ protozoon ${ }^{-1}$, respectively. This suggests that some of the protein in this fraction could have come from bacteria.

As well-fed protozoa produced volatile fatty acids from endogenous substrates $(45 \mathrm{pmol}$ $\mathrm{h}^{-1}$ protozoon $^{-1}$ over $24 \mathrm{~h}$ ), it was difficult to determine the amount and proportions of 
these produced from non-radioactive substrates. On addition of $\left[{ }^{14} \mathrm{C}\right]$ cellulose or rice starch, there was no increase or a decrease (up to $35 \%$ ) in the rate of production over $24 \mathrm{~h}$. On incubation of starved protozoa (100000 organisms of isolate $\mathrm{w}$ grown in vitro) with cellulose or rice starch $(4 \mathrm{mg})$ in the presence of ampicillin $\left(1 \mathrm{mg} \mathrm{m}^{-1}\right)$, the following amounts of short chain fatty acids were produced, respectively, in $24 \mathrm{~h}$ (in pmol h-1 protozoon ${ }^{-1}$, with production in the absence of substrate in parenthesis): acetic acid, 7.40, 9.26 (1.28); propionic acid, $0 \cdot 60,1 \cdot 10(0 \cdot 17)$; butyric acid, $2 \cdot 60,2 \cdot 72(0 \cdot 25)$. In the absence of substrate the protozoa were dead after $24 \mathrm{~h}$.

Starch. On incubation of $\left[{ }^{14} \mathrm{C}\right]$ starch grains $(430 \mu \mathrm{g})$ with washed $E$. maggii (12600 organisms of isolate $\mathrm{W}$ grown in vitro) for $5.5 \mathrm{~h}$ in the absence or presence of chloramphenicol $\left(80 \mu \mathrm{g} \mathrm{ml}^{-1}\right)$, the respective distributions of ${ }^{14} \mathrm{C}$ were: $6 \%$ and $6 \%$ in the 'bacterial fraction' probably as free starch grains, $25 \%$ and $17 \%$ as volatile fatty acids in the medium, $2 \%$ and $26 \%$ as non-volatile material [as maltose ( $40 \%$ ) and glucose $(60 \%)$ ] in the medium and $12 \%$ and $8 \%$ in the protozoa. The remaining material was probably $\mathrm{CO}_{2}$. Of the protozoal ${ }^{14} \mathrm{C}$ in the absence of antibiotic, $35 \%$ was in the broken-cell supernatant fluid and of this, $64 \%$ was in the pool, $20 \%$ in the hot TCA-soluble fraction and $16 \%$ in protein. This was equivalent to a synthesis of $41.6 \mathrm{pg} \mathrm{h}^{-1}$ protozoon ${ }^{-1}$. In the pellet fraction the rate was $157 \mathrm{pg} \mathrm{h}^{-1}$ protozoon $^{-1}$. In the presence of chloramphenicol, protein was synthesized at rates of 14.6 and $39.4 \mathrm{pg} \mathrm{h}^{-1}$ protozoon ${ }^{-1}$ in the broken-cell supernatant fluid and pellet fractions, respectively. These results suggest that in the absence of antibiotic some of the protein in both fractions was bacterial or derived from bacteria.

Glucose. Although glucose is not normally present at high concentrations in the rumen, except just after feeding, it is the major product of the digestion of cellulose and starch and was taken up from the medium by $E$. maggii (isolate w grown in vitro) at a rate of $14 \mathrm{pmol}$ $\mathrm{h}^{-1}$ protozoon ${ }^{-1}$ (measured over $3.5 \mathrm{~h}$ ) at infinitely high glucose concentration (determined as described by Coleman, 1967). Of the ${ }^{14} \mathrm{C}$ recovered after uptake of $0 \cdot 19 \mu \mathrm{mol}$ [U-14 $\mathrm{C}$ ]glucose by 12000 protozoa during $4 \mathrm{~h}$ from a $0.067 \mathrm{~mm}$ solution in the absence of antibiotic, $40 \%$ was in the broken-cell supernatant fluid. This was distributed between the pool $(75 \%)$, hot TCA-soluble fraction $(18 \%)$ and protein $(7 \%)$. The incorporation into protein represents a conversion of glucose-carbon into protein of $20 \mathrm{pg} \mathrm{h}^{-1}$ protozoon ${ }^{-1}$. In the broken-cell pellet, $34 \%$ of the ${ }^{14} \mathrm{C}$ was present in protein and $57 \%$ in a glucose-containing polysaccharide. On disruption of the protozoa before incubation with $\left[{ }^{14} \mathrm{C}\right]$ glucose, incorporation into the broken-cell pellet was increased by $120 \%$, and of the ${ }^{14} \mathrm{C}$ taken up, $42 \%$ was in protein. As the uptake was sensitive to chloramphenicol $(90 \%$ decrease in incorporation in the presence of $80 \mu \mathrm{g} \mathrm{ml}^{-1}$ ), this suggested that it was due to the action of bacteria in the pellet. With intact protozoa, incorporation into the hot TCA-soluble and protein fractions was decreased in the presence of chloramphenicol by $34 \%$ and $87 \%$, respectively, in the broken-cell supernatant fluid and by $0 \%$ and $44 \%$ in the broken-cell pellet, suggesting that some of the protein was, or was derived from, bacterial protein. The distribution of amino acids in the protein was similar under all conditions with aspartic acid, glutamic acid and alanine being most heavily labelled and trace amounts of ${ }^{14} \mathrm{C}$ in glycine, arginine, lysine, proline and serine.

\section{Cellulase}

The rate of release of soluble ${ }^{14} \mathrm{C}$-labelled compounds from phosphoric acid-regenerated $\alpha-\left[{ }^{14} \mathrm{C}\right]$ cellulose by protozoal broken-cell supernatant fluid declined progressively with time (Fig. 2). In this experiment $70 \%$ of the cellulose was digested in $48 \mathrm{~h}$ but in others over $90 \%$ digestion was obtained. The amount of ${ }^{14} \mathrm{C}$ released after any time was not proportional to the concentration of broken-cell supernatant fluid, the rate per unit volume of fluid decreasing with increasing concentration of fluid (Fig. 3). However, the amount of ${ }^{14} \mathrm{C}$ released was proportional to the amount of $\left[{ }^{14} \mathrm{C}\right]$ cellulose added initially. The optimum $\mathrm{pH}$ for digestion was $5 \cdot 7$ to $6 \cdot 2$ (Fig. 4). At pH 6.0 the amount of ${ }^{14} \mathrm{C}$ released was slightly greater 


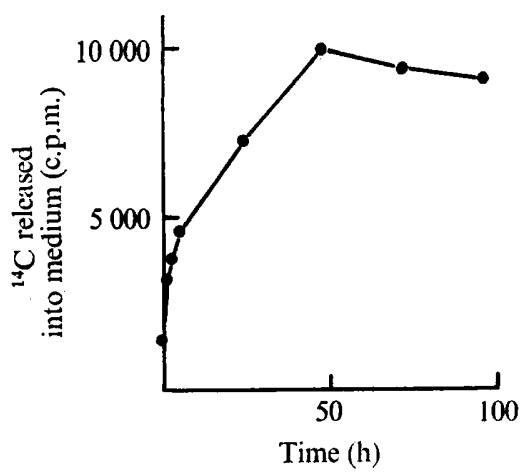

Fig. 2. Release of ${ }^{14} \mathrm{C}$ from $\left[{ }^{14} \mathrm{C}\right]$ cellulose $(14400$ c.p.m.) by the broken-cell supernatant fluid from 7150 protozoa.

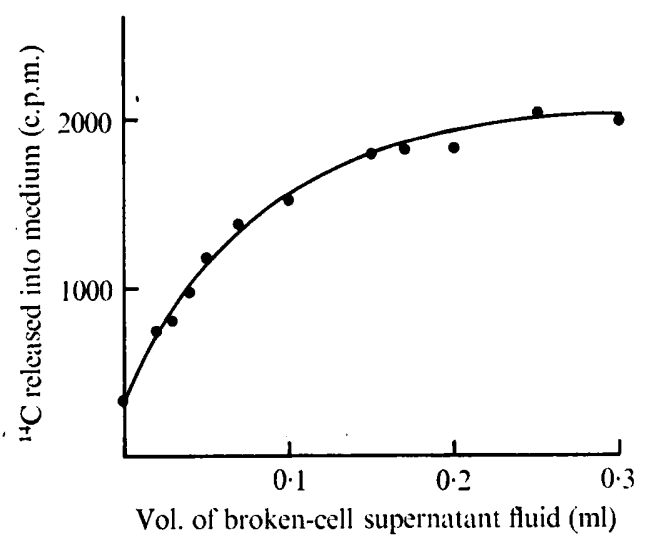

Fig. 3

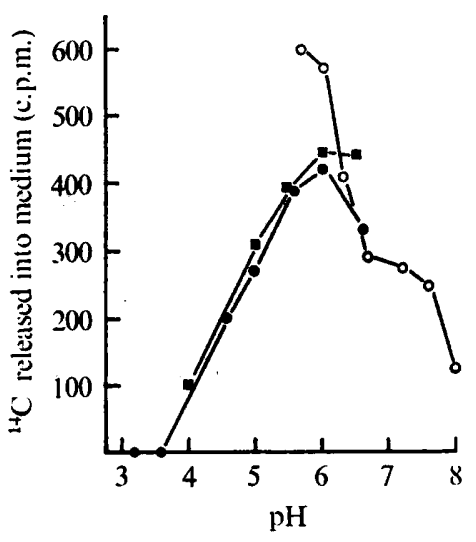

Fig. 4

Fig. 3. Effect of the concentration of broken-cell supernatant fluid ( $1 \mathrm{ml}$ equivalent to 79000 protozoa) on the release of ${ }^{14} \mathrm{C}$ from $\left[{ }^{14} \mathrm{C}\right]$ cellulose $(9500$ c.p.m.) during $5 \mathrm{~h}$ incubation.

Fig. 4. Effect of $\mathrm{pH}$ on the release of ${ }^{14} \mathrm{C}$ from $\left[{ }^{14} \mathrm{C}\right]$ cellulose $(8000$ c.p.m.) by the broken-cell supernatant fluid from 2200 protozoa during $6 \mathrm{~h}$ incubation in: $\mathbf{m}, 0 \cdot 1 \mathrm{M}$ - $\beta \beta^{\prime}$-dimethylglutarate buffer; $0,0 \cdot 2 \mathrm{M}-\mathrm{Na}_{2} \mathrm{HPO}_{4} / 0 \cdot 1 \mathrm{M}$-citric acid buffer; $O$, salt solution $\mathrm{D}$ (Coleman, 1972) adjusted to the $\mathrm{pH}$ value shown.

(15 to $21 \%$ ) in salt solution $\mathrm{D}$ than in phosphate/citrate buffer or $\beta \beta^{\prime}$-dimethylglutarate buffer (Fig. 4) although the addition of $\mathrm{CaCl}_{2}$ or $\mathrm{MgCl}_{2}$ (each at 1 or $10 \mathrm{~mm}$ ) to the latter buffer was not stimulatory. Glucose was the major (over $90 \%$ ) digestion product unless cellobiose was added to the digestion mixture when, after $4 \mathrm{~h}, 60 \%$ of the ${ }^{14} \mathrm{C}$ was present as cellobiose (for method of identification see Coleman, 1969).

In experiments made under standard conditions where less than $20 \%$ of the $\left[{ }^{14} \mathrm{C}\right]$ cellulose was digested in 4 to $5 \mathrm{~h}$, the rate of digestion by the enzyme in the broken-cell supernatant fluid was, with isolates $\mathrm{CO} 2$ and $4 \mathrm{~L}, 11 \cdot 0 \pm 5 \cdot 7 \mathrm{pg} \mathrm{h}^{-1}$ protozoon $^{-1}(n=16)$ and with isolate $\mathrm{C}$, $28 \cdot 4 \pm 8 \cdot 1 \mathrm{pg} \mathrm{h}^{-1}$ protozoon $^{-1}(n=4)$. These are equivalent to $0.46 \pm 0.24$ and $3.3 \pm 0.9 \mu \mathrm{g}$ cellulose digested $\mathrm{h}^{-1}(\mathrm{mg} \text { protein })^{-1}$, respectively.

Digestion of cellulose by disrupted protozoa. Disruption of protozoa markedly increased the amount of ${ }^{14} \mathrm{C}$ released from $\left[{ }^{14} \mathrm{C}\right]$ cellulose during short $(5 \mathrm{~h})$ incubations, probably due to the release of intracellular enzymes (Table 1). The supernatant fluid obtained after centrifuging the disrupted protozoa at low speeds $(200 \mathrm{~g}, 20 \mathrm{~s})$ was often more active than the starting homogenate, possibly due to the removal of cellulosic fragments that would compete with the $\left[{ }^{14} \mathrm{C}\right]$ cellulose for enzyme during the assay. Little activity $(<25 \%)$ was 
Table 1. Cellulase activity of fractions of Eudiplodinium maggii grown in vivo

Washed protozoa were disrupted by sonication in an ultrasonic cleaning bath (average output $40 \mathrm{~W}$ and frequency $80 \mathrm{kHz}$ ) at room temperature until no protozoa could be detected microscopically, and the homogenate was then centrifuged $(200 \mathrm{~g}, 20 \mathrm{~s})$. The resulting supernatant was centrifuged successively at two higher speeds. The pellet from each sedimentation was washed once and made up to the original volume with salt solution $\mathrm{D}$ containing $0 \cdot 1 \%$ cysteine hydrochloride, before assaying $0.1 \mathrm{ml}$ of each fraction for cellulase activity. Activities are expressed relative to that of broken-cell supernatant fluid (taken as 100) - see Methods.

$$
\text { Fraction } \quad \begin{gathered}
\text { Cellulase } \\
\text { activity }
\end{gathered}
$$

Intact protozoa 10

Sonicated protozoa 90

Supernatant fluid $(200 \mathrm{~g}, 20 \mathrm{~s}) \quad 152$

Supernatant fluid $(5500 \mathrm{~g}, 20 \mathrm{~min}) \quad 100$

Pellet (5500 g, $20 \mathrm{~min}) \quad 17$

Supernatant fluid $(114000 \mathrm{~g}, 60 \mathrm{~min}) \quad 90$

Pellet $(114000 \mathrm{~g}, 60 \mathrm{~min}) \quad 16$

\title{
Table 2. Effect of antibiotics on the cellulase activity in Eudiplodinium maggii
}

\begin{abstract}
Washed protozoa $\left(1.26 \times 10^{6}\right.$ grown in vivo $)$ were incubated anaerobically for $22 \mathrm{~h}$ in salt solution D containing $0.1 \%$ cysteine hydrochloride, with or without ampicillin $\left(1 \mathrm{mg} \mathrm{ml}^{-1}\right)$ or chloramphenicol $\left(60 \mu \mathrm{g} \mathrm{ml}^{-1}\right)$ and with or without cellulose $\left(2 \cdot 3 \mathrm{mg} \mathrm{ml}^{-1}\right)$. The protozoa were then disrupted by sonication (see Methods) and centrifuged $(5500 \mathrm{~g}, 20 \mathrm{~min}$ ) to produce the broken-cell supernatant fluid; the pellet after washing once was the broken-cell pellet. Cellulase activities are expressed relative to that of freshly prepared broken-cell supernatant fluid (taken as 100) - see Methods.
\end{abstract}

$\begin{array}{lccc}\text { Incubation conditions } & \begin{array}{c}\text { Cellulose } \\ \text { added }\end{array} & \begin{array}{c}\text { Cellulase activity in : } \\ \begin{array}{c}\text { Broken-cell } \\ \text { suntibiotic } \\ \text { fluid }\end{array}\end{array} & \begin{array}{c}\text { Broken- } \\ \text { cell } \\ \text { pellet }\end{array} \\ \text { No incubation } & \text { None } & 100 & 22 \\ \text { None } & \text { None } & 33 & 12 \\ \text { Chloramphenicol } & \text { None } & 33 & 7 \\ \text { None } & + & 21 & 22 \\ \text { Ampicillin } & + & 27 & 29 \\ \text { Chloramphenicol } & + & 22 & 23\end{array}$

recovered in the pellet fractions after centrifuging at $5500 \mathrm{~g}$ or $114000 \mathrm{~g}$ showing that most of the cellulase was not particulate and that the activity of the initial homogenate was not due to intact bacteria.

Effect on protozoal cellulase of pre-incubation with antibiotics. As $E$. maggii contains bacteria (Hungate, 1966) it was possible that the cellulase liberated on breakage of the protozoa was of bacterial rather than protozoal origin. This was investigated by measuring the cellulase activity of the protozoa $\left(1.26 \times 10^{6}\right.$, taken from the rumen) after incubation of the intact protozoa with or without antibiotics for $22 \mathrm{~h}$ in vitro (Table 2). In the absence of added substrate the activity of the broken-cell supernatant fluid decreased by $65 \%$ with or without ampicillin $\left(1 \mathrm{mg} \mathrm{ml}^{-1}\right)$ or chloramphenicol $\left(60 \mu \mathrm{g} \mathrm{ml}^{-1}\right)$ whereas that of the pellet fractions decreased by $45 \%$ with and 64 to $68 \%$ without the antibiotics. This different sensitivity of the activity in the two fractions suggests that the enzyme in the supernatant fluid was of protozoal origin and that in the pellet of bacterial origin. On incubation of the protozoa in the presence of cellulose $\left(2 \cdot 3 \mathrm{mg} \mathrm{ml}^{-1}\right)$ the results were less clear, but there was little or no fall in the activity of the pellet fraction under any condition. 


\section{DISCUSSION}

There is now considerable evidence that many of the larger Entodiniomorphid protozoa, e.g. Polyplastron multivesiculatum, Enoploplastron triloricatum, Diplodinium spp. and Eudiplodinium spp., can utilize cellulose because these species can grow on cellulosecontaining substrates in the absence of starch (see, for example, Hungate, 1942, 1943; Naga \& El-Shazly, 1968; Coleman et al., 1976). Washed suspensions have also been shown to degrade cellulose preparations (Hungate, 1943; Abou Akkada et al., 1963; Coleman et al., 1976) although Naga \& El-Shazly (1968) found that whereas Eudiplodinium (? Metadinium) medium apparently utilized barley hay, cell-free extracts were inactive against cellulose. Although Hungate (1943) showed microscopically that E. maggii synthesized 'paraglycogen' from cellulose, the present paper is the first study on the incorporation of ${ }^{14} \mathrm{C}$ from $\left[{ }^{14} \mathrm{C}\right]-$ cellulose by rumen protozoa. The results confirm that cellulose-carbon is incorporated into a glucose-containing polymer which is easily hydrolysed by acid and which is probably starch-like.

The fact that incubation with antibiotics has no effect on the level of cellulase in the cytoplasmic fraction (broken-cell supernatant fluid) confirms the suggestion of Hungate (1943) that the enzyme is not of bacterial origin although there may be a bacterial enzyme in the particulate fraction of the protozoa. Bacteria may be more important in the synthesis of protein from cellulose and starch. The presence of a chloramphenicol-sensitive protein synthesis in the cytoplasm suggests that bacteria in the protozoa synthesize protein from carbohydrate and are then digested by the protozoa with the liberation of amino acids that are synthesized into protein by the protozoa.

Although the experiments reported above were made with washed suspensions of E. maggii, which may not behave in the same way as growing organisms, the results can be used to obtain information on the importance of the protein synthesized from carbohydrate towards the total required by the protozoa for growth. As the protozoa have associated bacteria that are found after sonication in the broken-cell pellet, only incorporation into the broken-cell supernatant fluid will be considered. Each E. maggii organism (isolate w) grown in the rumen contained $24 \mathrm{ng}$ protein in this fraction and would have to synthesize $1.0 \mathrm{ng}$ protein $\mathrm{h}^{-1}$ to divide once each day. As each protozoon synthesized (in the absence of antibiotic) $41.6 \mathrm{pg}$ protein $\mathrm{h}^{-1}$ from starch, $2.9 \mathrm{pg} \mathrm{h}^{-1}$ from cellulose and $20 \mathrm{pg} \mathrm{h}^{-1}$ from glucose $(0.67 \mathrm{~mm})$, the mean generation times of protozoa using these carbohydrates as sole source of protein would be 580,8300 and $1200 \mathrm{~h}$, respectively. It is probable that when growing on starch or cellulose, which are its natural food materials, E. maggii obtains the remainder of the amino acids from the digestion of engulfed bacteria or from free amino acids as found with other Entodiniomorphid protozoa (Coleman \& Laurie, 1974).

The maximum rate of formation of short-chain fatty acids by E. mággii from endogenous substrate ( $45 \mathrm{pmol} \mathrm{h}^{-1}$ protozoon $\left.{ }^{-1}\right)$ is equivalent to a rate of $135 \mathrm{mmol} \mathrm{d}^{-1}$ in a sheep rumen of 2.51 fluid volume containing 50000 protozoa $\mathrm{ml}^{-1}$. As a sheep produces a total of $4 \mathrm{~mol}$ $\mathrm{d}^{-1}$ (Leng, 1970), the production of short-chain fatty acids by this protozoon accounts for less than $3.5 \%$ of the total. Although starch and cellulose are degraded to glucose their failure to stimulate the production of volatile fatty acids, except in protozoa that were almost dying of starvation, suggests that E. maggii like Entodinium caudatum (Coleman, 1969) possesses a mechanism for maintaining constant its intracellular glucose concentration and hence the rate at which it is metabolized.

I wish to thank Dr P. Kemp for inserting rumen cannulae into the sheep used to provide rumen fluid, Mr D. W. Grime for estimating fatty acids and D. C. Sandford and Y. S. Rutland for valuable technical assistance. 


\section{REFERENCES}

Abou Akkada, A. R., Eadie, J. M. \& Howard, B. H. (1963). The carbohydrases of Polyplastron multivesiculatum (Dogiel \& Fedorowa). Biochemical Journal 89, 268-272.

Abou Akkada, A. R., Bartley, E. E., Berube, R., FinA, L. R., MeYer, R. M., Hendricks, D. \& Julius, F. (1968). Simple method to remove completely ciliate protozoa of adult ruminants. Applied Microbiology 16, 1475-1477.

ColEmaN, G. S. (1958). Maintenance of oligotrich protozoa from the sheep rumen in vitro. Nature, London 182, 1104-1105.

Coleman, G.S. (1967). The metabolism of free amino acids by the rumen ciliate Entodinium caudatum. Journal of General Microbiology 47, 433-447.

Coleman, G. S. (1969). The metabolism of starch, maltose, glucose and some other sugars by the rumen ciliate Entodinium caudatum. Journal of General Microbiology 57, 303-332.

Coleman, G. S. (1972). The metabolism of starch, glucose, amino acids, purines, pyrimidines and bacteria by the rumen ciliate Entodinium simplex. Journal of General Microbiology 71, 117-131.

Coleman, G. S. \& Laurie, J. I. (1974). The metabolism of starch, glucose, amino acids, purines, pyrimidines and bacteria by three Epidinium spp. isolated from the rumen. Journal of General Microbiology 85, 244-256.

Coleman, G. S. \& Laurie, J. I. (1977). The metabolism of starch, glucose, amino acids, purines, pyrimidines and bacteria by the rumen ciliate Polyplastron multivesiculatum. Journal of General Microbiology 98, 29-37.

Coleman, G. S., Laurie, J. I., Bailey, J. E. \& HoldGate, S. A. (1976). The cultivation of cellulolytic protozoa isolated from the rumen. Journal of General Microbiology 95, 144-150.

Hugget, A. ST G. \& Nixon, D. A. (1957). Use of glucose oxidase, peroxidase and $o$-dianisidine in determination of blood and urinary glucose. Lancet ii, 368-369.

HuNGATE, R. E. (1942). The culture of Eudiplodinium neglectum, with experiments on the digestion of cellulose. Biological Bulletin. Marine Biological Laboratory, Woods Hole, Massachusetts 83, 303-319.

Hungate, R. E. (1943). Further experiments on the cellulose digestion by the protozoa in the rumen of cattle. Biological Bulletin. Marine Biological Laboratory, Woods Hole, Massachusetts 84, 157-163.

HUNGATE, R. E. (1966). The Rumen and its Microbes. New York: Academic Press.

JERMYN, M. A. (1955). Cellulose and hemicelluloses. In Modern Methods of Plant Analysis, vol. 2, pp. 197-225. Edited by K. Paech and M. V. Tracey. Berlin: Springer-Verlag.

LENG, R. A. (1970). Formation and production of volatile fatty acids in the rumen. In Physiology of Digestion and Metabolism in the Ruminant, pp. 406-421. Edited by A. T. Phillipson. Newcastle-upon-Tyne: Oriel Press.

Lowry, O. H., Rosebrough, N. J., FARR, A. L. \& RANDALL, R. J. (1951). Protein measurement with the Folin phenol reagent. Journal of Biological Chemistry 193, 265-275.

NaGA, M. A. \& El-Shazly, K. (1968). The metabolic characterization of the ciliate protozoon Eudiplodinium medium from the rumen of buffalo. Journal of General Microbiology 53, 305-315. 